\title{
Research on the Characteristics and Evaluation of Distance Teachers' Education and Teaching
}

\author{
Meixiu Zhou \\ Zhejiang Radio and Television University, Hangzhou, China \\ Email: zwy950120@163.com
}

How to cite this paper: Zhou, M.X. (2021) Research on the Characteristics and Evaluation of Distance Teachers' Education and Teaching. Open Access Library Journal, 8: e6983.

https://doi.org/10.4236/oalib.1106983

Received: November 12, 2020

Accepted: January 8, 2021

Published: January 11, 2021

Copyright $\odot 2021$ by author(s) and Open Access Library Inc.

This work is licensed under the Creative Commons Attribution International License (CC BY 4.0).

http://creativecommons.org/licenses/by/4.0/

(c) (i) Open Access

\begin{abstract}
Radio and Television University is different from ordinary universities in its multi-educational characteristics. It has a distance and open teaching mode, a wide range of complex teaching objects and a teaching management team with profession. The teaching, teaching management and scientific research of TV university teachers are closely centered on the construction of learning resources with learners as the main body, and pay attention to learning support service, evaluation and management research. The teachers of TV university must have a broad subject background, solid education and teaching ability, a certain academic level, strong management and coordination ability and great information literacy, which requires the establishment of appropriate teacher evaluation methods.
\end{abstract}

\section{Subject Areas}

Education

\section{Keywords}

TV University Teacher, Teaching, Characteristic, Evaluation

\section{Question Raising}

Zhejiang Radio and Television University (hereinafter referred to as TV university) is composed of the provincial power senior school, 10 municipal TV university, 59 county level power and 11 directly affiliated colleges (branch schools, teaching sites). It is also a modern distance and open university with open education as its main body, diversified education and coordinated development of various education types. TV university is neither average college, nor the adult college that is not in average sense. It is a new form of higher education that uses modern educational technology for teaching and management. The educational 
background of TV university is integrated undergraduate, junior college, and secondary school education, and also undertakes adult non-academic education, community education and other forms of open distance education [1]. TV university has the following characteristics which are different from ordinary universities:

1) Open distance education and teaching mode.

The teaching work of TV university is obviously different from ordinary colleges. TV university adopts modern teaching means, through the comprehensive use of a variety of media, long-distance, large-area dissemination of teaching information, and open teaching methods. TV university has a wide range of majors, multiple levels of talent training standards, and diversified teaching tasks. TV university carries out overall planning, gradation running school, and gradation management. Teaching management has administrative levels.

\section{2) A wide range of complex educational objects.}

The main characteristic of TV university is the openness of running a school, such as the breadth of the object of education. TV university is a school without walls, which provides learning opportunities for all people, especially those who for various reasons have lost the opportunity to receive ordinary high and secondary education, regardless of age, gender, occupation, identity, and so on. Most of the students in TV university are adult on-the-job staff, with many types of jobs, large age span and complex teaching objects. According to the analysis of enrollment, in recent years, TV university students tend to be rural and younger, their cultural foundation is uneven, their learning ability is weak, their learning motivation is diversified, their age span is large, their occupation structure is complex and diverse, and their work-study contradiction is more prominent.

\section{3) Full-time and integrated teaching management team.}

The particularity of running a school in TV university system requires a team of both presiding teachers and management teachers. Teachers should not only be proficient in the professional knowledge of this discipline and similar disciplines, but also master the construction of learning resources, learning support services and evaluation ability. Especially, they should be equipped with skilled long-distance teaching management skills. TV university teachers are responsible for teaching, management, scientific research and social service, and pay more attention to the cultivation of students' independent learning.

In Zhejiang Province, in the outline of medium and long-term education reform and development plan, it is proposed that: "based on the radio and TV university, integrating higher education resources, and accelerate the construction of the Open University in Zhejiang Province". In the landscape orientation of education, Radio and Television University has changed from participating in the compensation of higher academic education to participate in the national lifelong education. These new development situations have given TV university both opportunities and great challenges. The teacher's team is the first task of 
the basic construction of TV university. The reasonable and effective evaluation of teacher education and teaching in TV university system can promote the construction of teacher team and the development of TV university education.

\section{Analysis on the Characteristics of TV University Teachers' Education and Teaching Work}

Radio and TV University (referred to as TV university) is engaged in modern open distance education of adult institutions of higher learning. Modern distance education is a new form of distance education produced with the development of modern information technology [2]. It relies on computer, communication technology and network technology, and adopts the modern teaching means of remote real-time two-way interactive multimedia to realize the educational transmission process across time and space. In our education system, modern distance education is a new army, in addition to the remote (network) part of the ordinary university college of education. Among them Radio and Television University is the largest scale and has the most extensive influence. Modern and open distance education is different from the traditional face-to-face education. The traditional face-to-face education teaching process is designed by teachers and it is carried out by teacher. On the modern open and distance education, the main body are learners. Modern open and distance education pays attention to the construction of learning resources, the learners' learning support services, evaluation and management. The teachers of TV university will overcome the traditional teaching habits, and establish students' autonomous learning centered teaching idea. To be the change of students' learning concept, the guide of learning method, the trainer of learning habit, the maintainer of learning motivation, the developer of learning potential, the designer and consultant of information resources, to improve the service consciousness and help guide students to learn independent learning. The following is a simple analysis of the characteristics of teaching, management and scientific research of TV university teachers.

1) Teaching characteristics of TV university teachers.

TV university is a school run by the central, provincial and prefecture-level system. Centiral Open University is responsible for formulating instructional teaching plans, providing various media teaching materials and other learning resources for corresponding courses, and taking charge of examination and proposition of corresponding courses. Provincial TV university formulates the corresponding implementation of the teaching plan, and organizes the implementation, guidance and inspection of grassroots TV university teaching process, organization of examination implementation and marking work. Grassroots TV universities (prefectures, cities and counties) employ guidance teachers, implement the implementation of the teaching plan, implement the teaching process, and provide student assistance services. TV university teachers at all levels have their own teaching objectives, and the whole teaching process is com- 
pleted by the cooperation of TV university teachers at all levels, forming a system of teaching team to assist the common completion.

The work connotation of teacher of TV university at all levels is not so simple as the above classification. Many teachers of TV university are not only professional hosting teachers, but also course responsible teachers, and more of course guidance teachers and guide teachers, and even assume the management and teaching tasks of many courses. The relative separation between teachers and students is a key mark of the difference between the TV university opening distance education and traditional education. The traditional common and higher education in teaching and learning of each link is basically in the school. The distance open education based on students as the center, is a kind of open mode, combing with the study guide. TV university's opening distance education emphasizes students' autonomous learning, emphasize the teacher's guidance, counselling to obey, the service to the students autonomous learning, emphasizes teachers provide students with a variety of information, resources, and implementation of the learning support services.

\section{2) Characteristics of teaching management of TV university teachers.}

TV university teachers carry out opening distance education, in addition to the general sense of the teaching work, but also assume a lot of teaching management work [3]. It includes the organization and development of various activities in student learning support services, the organization of face-to-face teaching, question-answering and online learning forums, and the release or feedback of teaching information and other teaching management work through distance education platform. Relative to regional RTVs, the provincial TV university teachers undertake more teaching organization and management work, responsible for organizing the grassroots TV university to implement the centralized practice teaching, organizing and guiding the teachers of related majors to use radio, TV, VBI, computer network and other means to implement distance teaching and teaching guidance, and provide various forms of teaching services to affiliated TV university; to manage, guide and monitor the teaching process of the TV university, especially the students' daily work, experiment, practice and social investigation by means of teaching inspection, teaching tour and examination tour; to organize and implement the evaluation of teaching materials; cooperate with superior TV university teaching materials evaluation; to organize and implement teacher training for majors and courses; set up university teaching and research office, relevant studies (association) association, collaborative group, project research group, etc, and organize and carry out teaching and research activities; organize the final examination marking work for relevant majors. Therefore, teachers of TV university should not only become the teaching expert, but also need to become the boost hand of students' learning activities, teaching and teaching management coordination.

3) Characteristics of teachers' scientific research work in TV university.

TV university is an institution of higher learning that implements distance 
open education. The function of TV university teachers is not only to undertake teaching and teaching management tasks, but also carriers out subject research and teaching reform research. But the educational teaching and scientific research work of the teachers is similar to that of ordinary universities teachers present different value orientations in TV universities, and teachers of TV university are guided by the theories and methods of distance and open education, centering on the rules of distance and open education rule and principle, teaching process, teaching design, teaching strategy and evaluation, and so on.

Based on TV university is open distance education, adult higher education and the particularity of the tertiary division of teaching and management system. The teaching and scientific research achievements of TV university teachers are more reflected in the theoretical research of open distance education and the exploration of teaching practice assisted by distance education technology, network learning course construction, multimedia CAI(IP) courseware competition, and so on. TV university teachers are more involved in central open university and provincial TV university organization of all kinds of teaching competition, all kinds of research projects, the achievement of awards of all kinds of excellent teaching scientific research, and awards of famous teachers and new teachers in TV university system. This is what TV university system is an effective means of improving the quality of personnel training. In order to promote the professional development of TV university teachers and the training quality of open and distance adult higher education, it is necessary to establish the evaluation index system of TV university teachers which is relatively independent from the evaluation standard of ordinary college teachers.

\section{Basic Requirements for Professional Quality of TV University Teachers}

Based on the characteristics of education and teaching in TV university, this paper puts forward some basic requirements for TV university teachers which are different from other series of teachers. From the connotation analysis, the TV university teacher contains three roles expectation, they are not only the university teacher, but also the adult education teacher, even the distance education teacher. TV university teachers are not only necessary to have the professional quality and subject level of teachers in colleges and universities, but also to study the characteristics of adults and solve the problem of how to learn and how to teach for adults with work-study conflicts; More importantly, the third generation of distance education based on the Internet requires TV university teachers to understand and be good at using the latest educational technology [4]. From the external market demand, TV university teachers have to face the subject field, teaching field, management field three aspects of work, not only teaching but also good management, to be the class director, responsible for teaching and logistics and other work. We think that TV university teachers should have the following basic requirements: 


\section{1) Broad academic background.}

Since many TV university teachers are not only professional hosting teachers, but also curriculum responsibility teachers, but also course guidance teachers and guidance teachers, and even have to undertake the management and teaching tasks of many courses, which would require the TV university teachers should not only to master their own discipline specialized knowledge [5], to insight into the development direction of the discipline, to grasps the subject research, practical understanding of the textual structure and layout system of the teaching material, familiar with the teaching material of the connection between the key difficulties and related disciplines of knowledge. In order to enable students to acquire the most cutting-edge knowledge, they also need a broad subject background and the ability to synthesize, infiltrate and integrate multi-disciplinary knowledge, so as to expand the scope of knowledge as much as possible, so as to adapt to the teaching requirements.

\section{2) Solid distance education teaching ability.}

Under the premise of having the basic theoretical knowledge of pedagogy, psychology and teaching methods, TV university teachers should especially master the characteristics, rules and methods of TV university teaching characters, familiar with the basic content, basic characteristics and basic methods of teaching management of TV University, and have solid teaching ability of distance education. First, according to the teaching plan formulated by the Central TV University, the teaching outline is formulated, to compile written teaching materials, to produce audio-visual teaching materials, to research and to develop network learning resources suitable for the learning characteristics and needs of distance education students, timely integrate all kinds of learning materials, and provide students with independent learning. Second, they must have the strong teaching cognitive ability (analysis teaching material, understand students' cognitive level, ability of teaching methods and teaching strategies), teaching design ability, teaching operation skills, teaching monitoring ability, etc. Third, they must have the solid specialized theory knowledge, study support service ability, guiding students to self-study, provide all-round, multi-level support services for students to learn, effectively manage the students' learning and formative assessment.

\section{3) A certain academic level.}

Education object's universality, long distance of education and teaching means, open the flexibility of teaching resources, learning support services of separability is different from the ordinary university such as the characteristics of the personnel training mode. If TV university teachers cannot in subject areas relatively deep research foundation and ability, they must have the certain academic level which adapts with the education teaching work. Should be targeted to carry out adult education teaching methodology, open and distance education technology, construction of learning resources and learning support services, research focusing on the teaching practice of distance open education, to carry 
out the corresponding teaching academic research, "Academic teaching" refers to that disseminates knowledge and improves teaching practice, research that provides academic support for specialty, curriculum construction and teaching and improves the teaching level and talent training quality of distance and open education [6].

\section{4) Strong ability of management and coordination.}

TV university student's individualized learning, collaborative learning, collective learning and practice teaching is inseparable from the teacher's organization and management, grassroots TV university teachers and part-time teachers' communication and contact, coordination with the course teacher, and superior TV university teachers' communication, teaching feedback, etc. TV university teachers have the strong organization management and coordination.

\section{5) Good information literacy.}

The characteristics of open and distance education in TV universities require teachers to have good information literacy, to have the ability of information selection, to have information collection, to have information judgment, to have information dissemination, to have information processing and information generation. Modern educational means require teachers to have skilled operation skills of multimedia distance teaching, to be able to make courseware, to correct online homework, to teach materials download, to answer online questions and so on. Building a network learning platform for students to truly realize the remote open education advantages of TV University which is "everybody, anytime, everywhere".

\section{Conclusions}

As of August 31, 2020, Zhejiang TV University has 5801 teaching and administrative staff, among which 1765 have senior titles. TV university teachers work in TV university, education and teaching, and research orientation reflects the characteristics of TV university work. This is fundamentally different from the educational and teaching characteristics and scientific research orientation of teachers in colleges and universities. In the title evaluation to be equal to the ordinary university teachers of the relevant indicators, it appears very biased.

The 19th National Congress of the Communist Party of China put forward the goal of "developing distance education and continuing education, and building a learning-oriented society in which all the people study and learn for life", which pointed out a bright prospect for the development of distance education. The construction of lifelong education system and learning society has opened up a new field for the development of TV university. The medium- and long-term educational reform and development plan of our province also clearly states, "Based on radio and television university, integrate higher education resources and accelerate the construction of Zhejiang Open University." Practice has proved that the construction of teaching staff is the key to the development of school education, and it is of far-reaching significance to promote the construc- 
tion of teaching staff in radio and television universities when they will assume more and more important social responsibilities in the construction of learning society and lifelong education system.

Guided by the scientific concept of development, in order to optimize the structure of teachers, improve the overall quality of teachers as the goal, by establishing comprehensive evaluation indexes suitable for professional quality and job performance of TV university teachers, guiding teachers in TV university system to carry out their work around the core of distance open education and teaching, and promoting the implementation of the educational objectives and tasks of distance open education courses in radio and television universities; To give full play to the guiding role of professional and technical qualification evaluation, so as to improve the quality of personnel training and social serviceability of TV university system, and promote the scientific and harmonious development of adult higher education in our province.

\section{Conflicts of Interest}

The author declares no conflicts of interest regarding the publication of this paper.

\section{Fund Project}

This paper is the result of the stage of "Research on the change of teacher identity in the development process of distance education-from the perspective of radio and TELEVISION university", a planned and funded project of Education science in Zhejiang Province (No. 2020SCG242).

\section{References}

[1] Dong, W. (2020) Research on Role Allocation and Competence of Distance Education Teachers. Journal of Heihe Students, No. 9, 89-91.

[2] Wang, W. (2019) Research on Teachers' Quality Demands in Open Universities under Distance Education Environment-A Case Study of Jiangsu Open University. Xinjiang Radio and Television University, No. 2, 1-5.

[3] Peng. H. (2018) Research on the Construction of Modern Distance Education Teachers. Journal of Tianjin TV University, No. 4, 20-23.

[4] Zhou, H. (2018) Empirical Analysis of Teacher Competence Framework of Distance Education in the New Era. China Adult Education, No. 21, 63-67.

[5] Zhao, Y. and Hao, H. (2018) Discussion on the Transformation and Realization Path of Teachers' Role in the Fourth Generation of "Distance Education". Vocational Education Forum, No. 9, 116-120.

[6] Xia, J. (2017) Role and Professional Development of Distance Education Teachers under Lifelong Education System. Research on Continuing Education, No. 6, 82-84. 